\title{
Rational Antibiotic Use: How Much Can Duration of Antibiotic Therapy Be Shortened?
}

\author{
Akııı Antibiyotik Kullanımı: Antibiyotik Tedavi Süresi Ne Kadar Kısaltılabilir?
}

\author{
(1) Gürdal YILMAZ1, (1) Serhat ATALAR1, (1) Uğur KOSTAKOĞLU2 \\ ${ }^{1}$ Karadeniz Technical University Faculty of Medicine, Department of Infectious Diseases and Clinical Microbiology, Trabzon, Turkey \\ ${ }^{2}$ Recep Tayyip Erdoğan University Faculty of Medicine, Department of Infectious Diseases and Clinical Microbiology, Rize, Turkey
}

\section{Abstract}

Infectious diseases are conditions with significant consequences in terms of public health while associated mortality, morbidity, and complications can be prevented. Disease severity and duration can be shortened by means of rational antimicrobial therapy. It is important to obey main rational antibiotic use rules ie. to collect and examine appropriate culture specimens before treatment, identify potential microbial agents, consider the pharmacological properties of the antibiotic, determine whether combined antibiotics are indicated, review the host factors and indications for antibiotic therapy modification, and monitor response to antibiotic therapy while planning antibiotic therapy. Once correct diagnosis has been made, the correct antibiotic must be administered via the correct route, at an effective dose, at optimum intervals, and for an appropriate length of time for rational antimicrobial therapy. However, knowledge concerning the optimal duration of treatment is limited. Patients generally receive antibiotic therapy for 10-14 days. Prolonged treatment is also common. Duration of antimicrobial therapy may be a confusing issue for clinicians due to problems of resistance and toxicity. A healthy bacterial ecosystem (i.e. a normal flora) is essential to remain healthy. Antibiotic use can alter the normal bacterial flora in humans, which generally leads to the emergence of multidrug-resistant (MDR) bacteria and side effects such as diarrhea. Infections caused by MDR bacteria result in increased disease and mortality rates and extended hospital stays, as well as increased costs. Studies aimed at shortening the duration of treatment have reported that a 3-5 day treatment period in some of the community-acquired infections and one-week period in some of the nosocomial infections may be sufficient. Based on the patients' individual characteristics and clinical responses to treatment, short-term antibiotic therapy may be administered in selected patient groups both in community-acquired and healthcare-associated infections. Rational antibiotic therapy, together with observation of response to treatment and optimal treatment durations (which remain to be determined) can prevent adverse outcomes associated with long-term antibiotic use such as antibiotic-related side effects and development of MDR bacteria.

Keywords: Duration of antibiotic therapy, short-term antibiotic therapy, antibiotic stewardship, pneumonia, rational antibiotic therapy

\section{Öz}

Enfeksiyon hastalıkları, akılcı antimikrobiyal tedavi ile mortalite, morbidite ve komplikasyonların önlenebileceği, hastalık şiddet ve süresinin kısaltılabileceği, halk sağlığı açısından önemli sonuçları olan hastalıklardır. Antibiyotik tedavisi planlanırken; antibiyotik tedavisinin gerekçelerinin saptanması, tedavi öncesi uygun örnek alınması ve incelenmesi, etken olabilecek mikroorganizmaların belirlenmesi, antibiyotiğin farmakolojik özelliklerinin bilinmesi, kombine antibiyotik endikasyonunun olup olmadığının belirlenmesi, konakçı faktörlerinin gözden geçirilmesi, antibiyoterapi değiştirme endikasyonlarının saptanması ve antibiyotik tedavisine yanıtın izlenmesi ilkelerine uyulmalıdır. Akılcı antimikrobiyal tedavi için doğru tanı sonrası doğru antibiyotik en uygun yoldan, etkin dozda, optimum aralıklarla, uygun süreyle verilmelidir. Ancak, başlanan tedavinin optimal süresine ilişkin bilgiler kısıtııır. Hastalar çoğunlukla 10-14 gün antibiyotik tedavisi almaktadır. Tedavi süresinin uzatıldığı durumlarla da sıkça karşılaşılmaktadır. Antimikrobiyal tedavi süresinin uzunluğu, direnç ve toksisite sorunları nedeniyle klinisyenlerin kafasını karıştıran bir sorun oluşturmaktadır. Sağlıklı kalmak için, sağlıklı bir bakteri ekosistemine, yani normal floraya ihtiyaç vardır. Antibiyotik kullanımı, insanlardaki normal bakteriyel floranın değişmesine bu da genelde çoklu antibiyotik dirençli bakterilerin ortaya çıkmasına ve ishal gibi yan etkilerin görülmesine neden olabilmektedir. Çok ilaca dirençli bakterilerin yol açtığı enfeksiyonlar, hastalığın ve ölüm oranlarının artması ve hastanede geçirilen sürenin uzaması ile sonuçlanmakta, ayrıca tedavi maliyetlerinde de artışa neden olmaktadır. Tedavi süresinin kısaltılmasına yönelik çalışmalarda bazı toplum kaynaklı 
enfeksiyonlarda 3-5 günlük, bazı hastane kaynaklı enfeksiyonlarda bir haftalık tedavi süresinin yeterli olabileceği belirtilmektedir. Gerek toplum kaynaklı gerekse hastane kaynaklı enfeksiyonlarda seçilmiş hasta gruplarında hastaların bireysel özellikleri ve tedaviye klinik cevapları da göz önüne alınarak kısa süreli antibiyotik tedavisi verilebilir. Tedavi yanıtının izlenmesi ve belirlenecek optimum tedavi süresi ile birlikte akılcı antibiyotik uygulaması antibiyotik ilişkili yan etki ve çok ilaca dirençli enfeksiyon gelişimi gibi uzun süreli antibiyotik kullanımının getireceği olumsuzlukları önleyebilecektir.

Anahtar Kelimeler: Antibiyotik tedavi süresi, kısa süreli antibiyotik, antibiyotik yönetimi, pnömoni, akılcı antibiyotik tedavisi

\section{Introduction}

Mortality, morbidity, aclinical severity, and complications associated with infectious diseases are preventable and may be reduced via rational antimicrobial therapy ${ }^{[1]}$. The discovery of antibiotics in the mid-twentieth century dramatically reduced morbidity and mortality resulting from infectious diseases and led to major changes in healthcare ${ }^{[2]}$.

The massive increase in the use of medicines, particularly antimicrobial drugs in recent years, has led to higher antibiotic resistance rates and costs and become an increasingly common cause of delays in proper treatment due to drug toxicity and diagnostic masking ${ }^{[2]}$. These problems gave rise to a new concept: rational drug use. Accordingly, patients should receive appropriate antimicrobials suiable to their clinical needs and individual characteristics, at an appropriate dose, for an appropriate period of time, and at the lowest $\operatorname{cost}^{[3]}$. World Health Organization estimates that more than 50\% of drugs are prescribed, dispensed, or sold inappropriately. In addition, half of patients fail to take their medicine properly ${ }^{[4]}$. This situation is no different in Turkey, and is in fact even more alarming. The aggregate consumption of systemic antimicrobials for 2011 was calculated as 46.70 [Defined Inhabitant Dose (DID)-defined daily dose per 1000 inhabitants per $24 \mathrm{~h}$ ], and among these drugs, the aggregate consumption of systemic antibacterial drugs was calculated as $42.28 \mathrm{DID}^{[5]}$. Unfortunately these rates place Turkey the first among European countries in antimicrobial consumption $^{[6]}$. These data demonstrate the absolute necessity of practicing rational antibiotic therapy. In the rational use of medicines (RUM) concept, responsibility lies with the doctor prescribing the medicine, the pharmacist dispensing the medicine under appropriate conditions, the nurse administering the medicine, and the patient receiving the treatment ${ }^{[4]}$. It is apparent that the issue is multidimensional. Our aim in this article is not to discuss all of these dimensions, but to examine the importance of treatment duration as one component of RUM and to raise awareness of this issue.

\section{Rational Antimicrobial Therapy}

For rational antimicrobial therapy, an accurate diagnosis should be followed by administering the correct antibiotic via the most appropriate route, at an effective dose, at optimum intervals, and for an appropriate period of time $e^{[7,8]}$.
However, there is limited information regarding optimal treatment duration. Patients generally take antibiotics for 1014 days while more prolonged treatment is also common. The duration of antimicrobial treatment can be a confusing issue for clinicians due to problems with antibiotic resistance and toxicity $^{[9]}$. Some of the problematic multidrug-resistant (MDR) pathogens are carbapenem-resistant Acinetobacter baumannii and Pseudomonas aeruginosa, extended-spectrum $\beta$-lactamase (ESBL) producer and carbapenem-resistant Enterobacteriaceae, and methicillin- resistant Staphylococcus aureus (MRSA) ${ }^{[10]}$. The best way to reduce the emergence of MDR nosocomial strains is the rational use of antimicrobials ${ }^{[11]}$. This requires following guidelines for diagnosis and treatment, implementing antimicrobial de-escalation, avoiding the treatment of colonizations, monitoring serum levels of antimicrobials, and determining the appropriate duration of antibiotic therapy ${ }^{[12]}$.

\section{The Basic Principles of Rational Antibiotic Use}

There are several principles that should guide clinicians while planning of antibiotic therapy. These include identifying the indication for antibiotic use, obtaining and analyzing an appropriate specimen before initiating treatment, and identifying the likely causative microorganisms. Also important are knowing the pharmacological properties of the antibiotic, evaluating host factors, and determining whether there are indications for combined antibiotic use. Finally, indications for changing antibiotherapy should be determined and treatment response must be monitored ${ }^{[13]}$. These principles are indispensable for all clinicians and particularly for Infectious Diseases and Clinical Microbiology specialists. The factors influencing antibiotic use are presented in Table 1.

1. First, questioning the need for antibiotics is important in preventing unnecessary antibiotic use, particularly in viral infections ${ }^{[14]}$. There is evidence showing that antibiotics are not necessary for many cases of respiratory tract infections and that the patient's immune system is capable of fighting minor infections. Although the Turkish Ministry of Health has called attention to the misuse of antibiotics in treating influenza through recent public service advertisement campaigns, it is clear that both the public and physicians need constant reminders and that these campaigns should be repeated. Another incorrect but common practice is the prolonged use of antibiotics as prophylaxis after clean surgical procedures ${ }^{[15]}$. 
Table 1. Factors influencing antibiotic use

\begin{tabular}{l|l}
\hline \multirow{2}{*}{ Patient factors } & Usage at incorrect dose or duration \\
\cline { 2 - 2 } & Mistrust of patient to physician \\
\cline { 2 - 2 } & Requests for nonindicated antibiotic use \\
\cline { 2 - 2 } & $\begin{array}{l}\text { Using medicines based on advice from } \\
\text { nonmedical persons and obtaining them } \\
\text { from pharmacies without a prescription }\end{array}$ \\
\cline { 2 - 2 } & $\begin{array}{l}\text { Nonadherence to lifestyle changes } \\
\text { recommended to complement medical } \\
\text { treatment and recommended follow-up } \\
\text { during treatment }\end{array}$ \\
\hline Physician factors & Adequate and current scientific knowledge \\
\cline { 2 - 2 } & $\begin{array}{l}\text { Relationships with the pharmaceutical } \\
\text { industry }\end{array}$ \\
\cline { 2 - 2 } & Outdated information \\
\cline { 2 - 2 } & Habit \\
\hline Institutional factors & Workload and staff number \\
\cline { 2 - 2 } & Infrastructure \\
\cline { 2 - 2 } social factors & Relationships with health personnel \\
\cline { 2 - 2 } & Relationships with regulatory agencies \\
\hline \multirow{5}{*}{\begin{tabular}{l} 
Cultural and social factors \\
\cline { 2 - 2 }
\end{tabular}} & \begin{tabular}{l} 
Economic and legal factors \\
\hline
\end{tabular}
\end{tabular}

2. When antibiotherapy is indicated, appropriate culture samples obtained before initiating treatment enable the selection of a more effective spectrum and facilitate a faster treatment response, thus reducing any possible delays due to treatment-based diagnosis ${ }^{[2]}$. Narrow-spectrum antibiotics may be prescribed based on culture results, which reduces possible antibiotic resistance. Antibiotic use can alter the normal bacterial flora in humans, often leading to the emergence of MDR bacteria and side effects such as diarrhea. Antibiotic resistance has become a major global health problem. One of the best examples of the importance of performing bacteriological culture prior starting treatment is patients with chronic conditions such as vertebral osteomyelitis due to the high incidence of tuberculosis in Turkey ${ }^{[16,17]}$.

3. The pharmacological properties and tissue distribution of drugs are also important when selecting antibiotics ${ }^{[18,19]}$. In central nervous system infections, antibiotics with good penetration into the cerebrospinal fluid must be selected for successful treatment. Antibiotics which are unable to reach therapeutic levels in some tissues should not be preferred. It should be kept in mind that obesity and cachexia may influence drug doses.

4. After establishing an indication for antibiotic use and obtaining appopriate samples, failure to evaluate the possible causative microorganisms may result in the selection of incorrect treatment, even if an antibiotic with high target tissue penetration is selected. Inability to test for antibiotic drug level, bactericidal activity, or synergy are also seen as important problems ${ }^{[19,20]}$.

5. Both antibiotic and patient characteristics are important in treatment selection. Comorbidities and drug interactions are generally overlooked during antibiotic selection. The Infectious Diseases Society of America (IDSA) 2016 guidelines for antibiotic stewardship emphasize that this may result in low or high serum concentration of the given drug and lead to treatment failure; therefore, serum concentrations of many drugs, particularly amikacin, vancomycin, and voriconazole, should be assessed in order make necessary dose adjustments ${ }^{[2]}$.

6. The need for combination antibiotic treatment should also be evaluated. Although combination antibiotic therapy is recommended for specific illness such as multidrug-resistant A. baumannii infections, tuberculosis, and brucellosis, it has been emphasized that not all antibiotic combinations are beneficia $^{[21,22]}$. Lepper and Dowling ${ }^{[23]}$ clearly demonstrated in 1951 that penicillin alone is more effective in the treatment of pneumococcal meningitis than the combination of penicillin and chlortetracycline. The mortality rate was 21\% among patients treated with penicillin monotherapy, compared to 79\% among those treated with combined penicillin and chlortetracycline. Another study involving pediatric meningitis demonstrated the superiority of monotherapy over an antagonistic drug combination. Mathies et al. ${ }^{[24]}$ treated a group of children with bacterial meningitis using only ampicillin or ampicillin + chloramphenicol + streptomycin combination. They reported 4.3\% mortality among 140 children treated only with ampicillin and 10.5\% among 124 children treated with combination antibiotics, which resulted in a significant difference. However, further studies suggest that clinically significant antagonism may also occur in patients with disrupted host defense mechanisms (e.g. cancer such as leukemia, neutropenia) or in serious infections (e.g. meningitis, endocarditis), and that this in vitro antagonism is not clinically significant in patients with normal host defense mechanisms ${ }^{[2,26]}$. In addition, the best known example of chemical antagonism related to route of drug administration is between aminoglycosides and antipseudomonal penicillins. These drugs chemically antagonize each other in the serum and should not be infused together ${ }^{[27]}$.

7. Policies for the rational use of antibiotics suggest reducing the use of antibiotics in industrial areas such as livestock production. Numerous studies have demonstrated a causal link between the antibiotics used to prevent infections in livestock animals and increasing antibiotic resistance in human pathogens ${ }^{[28-30]}$.

\section{Consequences of Irrational Drug Use}

The most common problems in irrational drug use are inattention to route of drug administration, treatment duration, and dosage. 
The excessive and unnecessary use of medicines, using multiple medicines without indication, consuming medicine with liquids other than water, using expired medicines, and inappropriate self-treatment outside physicians' recommendations are examples of irrational drug use ${ }^{[31]}$. Failure to practice RUM may result in lower treatment adherence, unwanted outcomes due to drug interactions, development of resistance to certain drugs, repeated or prolonged illnesses, higher incidence of adverse events, and increased treatment costs ${ }^{[32,33]}$.

\section{Normal Flora}

The normal human flora is one of the natural mechanisms of resistance against microorganisms. It starts forming at birth and is composed primarily of bacteria ${ }^{[34]}$. The composition of normal flora varies in different body sites and is affected by age, gender, hormonal changes, nutritional properties, and personal hygiene habits ${ }^{[35]}$. Intestinal flora plays an important role in vitamin $\mathrm{K}$ synthesis and nutrient absorption. It also has a protective effect against colonization and proliferation of pathogenic microorganisms. This effect is explained with the concept of bacterial interference, which refers to the competition between flora bacteria and pathogenic bacteria for nutrients, colonization sites, cell surface receptors, and other attachment sites ${ }^{[36,37]}$. For example, the anaerobic components of the intestinal flora inhibit the proliferation of Salmonella bacteria. Colicins are proteins encoded by plasmids which are synthesized by intestinal bacterial flora. These proteins bind to specific cell surface receptors on the target bacteria and induce cell lysis or attack specific intracellular components such as ribosomes. In the intestine, colicins are fatal for Escherichia coli and Salmonella and Shigella species ${ }^{[38]}$.

\section{The Normal Flora and Antibiotics}

A healthy microbial biosystem (i.e., a normal flora) is necessary to stay healthy. The use of antibiotics may cause changes in the normal bacterial flora, often leading to the emergence of antibiotic-resistant bacteria and to side effects such as diarrhea ${ }^{[4,39]}$. Infections caused by resistant bacteria result in higher rates of disease and mortality and extended hospital stays, as well as increased treatment costs ${ }^{[40]}$.

Antibiotic resistance is ability of bacteria to proliferate and cause infection despite the presence of an antibiotic. Using antibiotics for inappropriate reasons or in inappropriate ways may cause bacteria to become resistant to medical treatment ${ }^{[4]]}$. Although antibiotics are known to have short-term effects on the human microbiota, recent evidence shows that the effects of some antibiotics persist for longer periods. Both molecular and conventional approaches have demonstrated that the administration of antibiotics is followed by the emergence of a bacterial community in the microbiota that is either particularly sensitive or is resistant to the antibiotic ${ }^{[42-47]}$.
Antibiotherapy disturbs the balance of the normal flora. This balance is closely related to the duration of antibiotherapy. Especially with treatment lasting longer than 7 days, resistant strains have been shown to remain in the microbiota for up to 2 years $^{[2]}$.

\section{Treatment Duration}

Treatment of 7-14 days is generally sufficient for many of the infectious diseases, but individualizing the duration of antibiotic treatment has recently gained attention. Main factors influencing treatment duration are the virulence of the agent, comorbidity, clinical severity of the disease, presence of bacteremia, complications, and treatment response ${ }^{[48-50]}$.

Short-term therapy increases treatment adherence and patient satisfaction while reducing costs and side effects ${ }^{[49]}$. However, in spite of these positive aspects, the use of short-term therapy is limited among physicians due to doubt regarding the adequacy of treatment, concerns of relapse, and the belief that it will increase complication, mortality, and sequelae rates ${ }^{[49]}$.

Prolonged antibioitic use is a practice that may cause collateral damage, new infection with MDR microorganisms, infection of other patients with MDR microorganisms, and increased morbidity, mortality, and costs ${ }^{[49]}$.

"Collateral damage" refers to the unwanted effects observed in the bacterial ecology as a result of inappropriate or excessive use of antibiotics ${ }^{[51]}$. These effects manifest as superinfection with different bacteria or selection for resistant bacteria and the subsequent colonization/infection with MDR bacteria. The antibiotics most often associated with collateral damage are third-generation cephalosporins, fluoroquinolones, and carbapenems. Currently potential agents of collateral damage include MRSA, vancomycin-resistant enterococcus, ESBLproducing Gram-negative bacilli, and multidrug-resistant Acinetobacter spp. and Clostridum difficile. The growing use of extended-spectrum antibiotics, particularly in hospital settings, has made the problem of collateral damage more common. When deciding on the antibiotic therapy possible collateral damage must be considered in addition to the benefits of treatment ${ }^{[51]}$.

\section{Community-acquired Pneumonia}

Efforts to shorten the duration of antibiotic therapy are most notable in the area of community-acquired pneumonia. The problems of antibiotic resistance, side effects, and cost have always been the driving forces behind such efforts.

Peltola et al. ${ }^{[52]}$ carried out a study to investigate whether parenteral $\beta$-lactamase administered for 4 days was as effective as 7 days as parenteral antimicrobial therapy for 
pediatric inpatients. A group of patients aged 3 months to 15 years who had bacterial pneumonia, other respiratory tract infections, sepsis-like infections, and other acute infections were prospectively and randomly assigned to groups given parenteral penicillin or cefuroxime group for 4 or 7 days. In addition to blood and throat cultures, etiology was investigated by serology for 23 different agents. A probable etiology was not identified for 96 of the 154 children included in the study. The authors concluded that shortening parenteral $\beta$-lactamase treatment to 4 days for infections treated parenterally was safe, cost-effective, ecologically appropriate, and lowered the risk of hospital-acquired infection.

Schrag et al. ${ }^{[53]}$ investigated whether short-term, high-dose amoxicillin treatment reduced the risk of posttreatment carriage of resistant Streptococcus pneumoniae in children with respiratory tract infections. The study included 795 children aged between 6 and 59 months old who were prescribed antibiotics for respiratory tract diseases. The children were randomly assigned to amoxicillin regimens of $90 \mathrm{mg} / \mathrm{kg}$ $(\mathrm{n}=398)$ daily for 5 days or $40 \mathrm{mg} / \mathrm{kg}(\mathrm{n}=397)$ daily for 10 days. Nasopharyngeal samples obtained from the patients on days 0 , 5,10 , and 28 were analyzed for carriage of penicillin-resistant $S$. pneumoniae. On day 28, the risk of carrying penicillin-resistant pneumococci was significantly lower in the short-term, highdose group (24\%) compared to the standard course group (32\%). Short-term, high-dose therapy had a stronger protective effect and treatment adherence was higher in families with 3 or more children.

Dunbar et al. ${ }^{[54]}$ investigated the efficacy of 10 day $500 \mathrm{mg}$ and 5 day $750 \mathrm{mg}$ levoxacin regimens in the treatment of atypical community-acquired pneumonia. The research was conducted in the USA as a randomized-controlled, double-blind, multicenter study. Of the 528 patients, 149 were diagnosed with atypical community-acquired pneumonia caused by Legionella pneumophila, Chlamydia pneumoniae, or Mycoplasma pneumoniae. Twenty-six of those were lost to follow-up and excluded, leaving 123 included in the analysis. The patients' initial symptoms and clinical presentation were reevaluated on day 3 of treatment and 7-14 days after the final dose of active drug. The clinical success rate was $95.5 \%$ for the $750 \mathrm{mg}$ group and $96.5 \%$ for the $500 \mathrm{mg}$ group. In the post-treatment analysis (31-38 days after treatment), relapse occurred in 2\% of the patients in both treatment groups. Patients receiving the high-dose, short-term therapy showed significantly greater fever reduction and symptom regression on day 3 of treatment.

In a study performed in Turkey ${ }^{[55]} ;$ KIter $^{[55]}$ analyzed the efficacy and safety of azithromycin (a single daily dose of $500 \mathrm{mg}$ for 3 days) in the outpatient treatment of adults with nonsevere community-acquired pneumonia. The study included 11 patients diagnosed in an outpatient clinic with community- acquired pneumonia based on clinical and radiological findings. Ten $(91 \%)$ of the 11 patients showed full recovery, $1(9 \%)$ had relapse, and $2(18 \%)$ experienced side effects related to treatment. Azithromycin therapy at $500 \mathrm{mg} /$ day for 3 days was reported to be safe and effective in the outpatient treatment of nonsevere community-acquired pneumonia, with a high rate of treatment adherence.

Socan ${ }^{[56]}$ compared the use of an azithromycin regimen of 500 $\mathrm{mg}$ on the first day followed by $250 \mathrm{mg}$ for 4 days (group 1) to a regimen of $500 \mathrm{mg}$ for 3 days (group 2) in the treatment of atypical pneumonia. Success rates were $80 \%$ in group 1 and $88 \%$ in group 2. Azithromycin had similar efficacy in treating adult atypical pneumonia when the same total dose was administered over 3 or 5 days.

In another study ${ }^{[57]}, 100$ adult patients diagnosed with community-acquired atypical pneumonia were randomly given azithromycin either as a single dose of $1.5 \mathrm{~g}$ or as $500 \mathrm{mg}$ for 3 days. Both groups had a clinical success rate of $97.9 \%$. It was concluded a single dose of $1.5 \mathrm{~g}$ azithromycin can be an alternative to the standard 3-day azithromycin regimen in the outpatient treatment of atypical pneumonia.

Hoepelman et al. ${ }^{[58]}$ compared treatment with amoxicillin/ clavulanic acid for 10 days and azithromycin for 3 days in patients with acute lower respiratory tract infection. Of the 144 patients included in the study, 123 had chronic bronchitis with type 1 acute exacerbation, 3 had pneumonia, and 18 had purulent bronchitis. Treatment success was 95\% in the azithromycin group and 90\% in the amoxicillin/clavulanic acid group. Success rates for the two groups were $77-66 \%$ at 30 -day follow-up and 66-59\% at 60-day follow-up, respectively. Mild adverse events occurred in 27 patients in the azithromycin group and 24 patients in the amoxicillin/clavulanic acid treatment group. The authors concluded that a 3-day regimen of oral azithromycin was as clinically and microbiologically effective as a 10-day amoxicillin/clavulanic acid regimen in treating acute lower respiratory tract infections.

Tellier et al. ${ }^{[59]}$ compared the efficacy and safety of 5- and 7-day oral telithromycin regimens and a 10-day clarithromycin regimen in patients with mild to moderate community-acquired pneumonia in a multicenter, double-blind, randomizedcontrolled study. The patients received telithromycin for 5 days (159 patients), telithromycin for 7 days (161 patients), or clarithromycin for 10 days (146 patients). Test-of-cure assessment after treatment showed clinical cure rates for telithromycin were 89.3\% (5 days) and 88.8\% (7 days), compared to $91.8 \%$ for clarithromycin. Eradication rates in the respective treatment groups were $95.8 \%, 96.7 \%$, and $88.5 \%$ for S. pneumoniae; $88.0 \%, 84.0 \%$, and $88.2 \%$ for Haemophilus 
influenza; and 1/1,4/5, and 3/4 for Moraxella catarrhalis. Telithromycin was found to have similar efficacy and safety to 10-day clarithromycin therapy.

In a meta-analysis of randomized controlled studies comparing short-term and long-term antibiotic regimens ${ }^{[60]}, 15$ studies including 2796 patients were evaluated. Short-term regimens used in the studies included azithromycin $(n=10), \beta$-lactamase $(n=2)$, fluoroquinolones $(n=2)$, and ketolides $(n=1)$; of the long-term regimens, the same antibiotic was used in 3 studies while antibiotics in the same class were used in 9. In general, no differences were observed between short-term and long-term regimens in terms of clinical failure [Odds ratio (OR): 0.89, 95\% confidence interval (CI): 0.78-1.02], mortality (OR: $0.81,95 \% \mathrm{Cl}: 0.46-1.43$ ) or bacteriological eradication (OR: 1.11, 95\% Cl: 0.76-1.62).

El Moussaoui et al. ${ }^{[6]]}$ performed a randomized, double-blind, placebo-controlled study among mild to moderate communityacquired pneumonia patients who improved after 3 days of intravenous treatment to compare the effectiveness of discontinuing treatment after 3 or 8 days. Patients who improved after receiving intravenous amoxicillin for 3 days were randomly administered oral amoxicillin $(n=63)$ or a placebo $(n=56) 3$ times a day for 5 days. Clinical success, symptoms, radiological findings, and adverse events were evaluated on days 10 and 28 . The results showed no difference between amoxicillin treatment for 3 days or 8 days in mild to moderate community-acquired pneumonia.

There have been very few prospective, well controlled studies in which the same antibiotic was used at the same dosage, only varying the treatment duration. However, these few studies suggest that azithromycin administered for less than 7 days (as short as 3 days) had similar efficacy with azithromycin given for longer durations in mild to moderate communityacacquired pneumonia ${ }^{[60,61]}$. The IDSA/American Thoracic Society guidelines currently recommend at least a 5-day course of antibiotics for adult patients with community-acquired pneumonia ${ }^{[50]}$. Similarly, the British Thoracic Society guidelines recommend a course of 7 days when treating mild to moderate community-acquired pneumonia ${ }^{[62]}$. The Pediatric Infectious Diseases Society and IDSA state that shorter treatment durations are more effective than a 10-day course in children with community-acquired pneumonia ${ }^{[62,63]}$. Longer treatment should be considered for severe disease, bacteriemic S. aureus pneumonia, or patients with cavitary lung disease. Outpatient care should be coordinated after discharge from hospital, as most patients with community-acquired pneumonia have longterm symptoms such as fever, cough, labored breathing, chest pain, expectorating, fatigue, or gastrointestinal symptoms. Comorbidities, especially cardiopulmonary or neurological disease, are the most common cause of early rehospitalization among clinically stabilized patients ${ }^{[64,65]}$.
In conclusion, current evidence indicates that mild to moderate community-acquired pneumonia can be effectively and safely treated with antibiotic therapy of 7 days or less. Reducing patients' antibiotic exposure may curb the rising rates of resistance to antimicrobial drugs, lower costs, and improve patient satisfaction and tolerance.

\section{Ventilator-associated Pneumonia (VAP)}

In patients hospitalized for any reason, pneumonia that develops within 48 hours after admission or within 48-72 hours after discharge and was not incubating during hospitalization is defined as nosocomial pneumonia ${ }^{[66]}$. Nosocomial pneumonia that develops at least 48 hours after endotracheal intubation in patients who do not exhibit the clinical picture of pneumonia or any clinical findings suggesting pneumonia at time of intubation and who receive invasive mechanical ventilation is defined as VAP ${ }^{[49]}$. VAP is a common healthcare-associated infection, seen in approximately $15-20 \%$ in patients admitted to intensive care units (ICU) ${ }^{[67]}$.

Studies investigating shortening treatment durations have suggested that 1 week of treatment may be sufficient ${ }^{[68,69]}$. The IDSA guidelines updated in July 2016 recommend 7-day treatment for both hospital-acquired pneumonia and VAP, and specify that the treatment can be extended to 14 days in cases caused by pathogens such as $A$. baumannii and $P$. aeruginosa $a^{[48]}$. However, short-term treatment is rarely given in daily practice.

In a study conducted in our hospital ${ }^{[49]}$ we evaluated the effectiveness of individualized treatment duration in VAP patients based on clinical response to an initial 5 days of antimicrobial treatment. The duration of antibiotic therapy was determined according to predetermined criteria and a 5-day clinical examination. Patients were divided into short-term (710 days) and long-term ( $>10$ days) antibiotic treatment groups. Nineteen patients were in the first group and 30 patients were in the second group. The groups were statistically equivalent in terms of demographical and clinical properties, Glasgow Coma Scale score, Clinical Pulmonary Infection Score (CPIS), and $\mathrm{PaO}_{2} /$ $\mathrm{FiO}_{2}$ ratio at time of VAP diagnosis ( $p>0.05$ ). The number of antibiotic-free days was $15.6 \pm 6.2$ in the short-term treatment group and $8.3 \pm 7.5$ days in the long-term treatment group $(p<0.0001)$. One patient in the short-term and 4 patients in the long-term treatment groups died within 28 days after treatment $(\mathrm{p}=0.348)$. The most common microorganisms in both groups were $A$. baumannii and $P$. aeruginosa. It was determined that treatment duration may be reduced to 1 week for VAP patients who show early clinical and laboratory response by monitoring fever, $\mathrm{CPIS}, \mathrm{PaO}_{2} / \mathrm{FiO}_{2}$ ratio, $\mathrm{CRP}$, and procalcitonin values.

Klompas et al. ${ }^{[70]}$ reported that patients with minimal and stable ventilator settings may be eligible for early discontinuation of antibiotic treatment. Of the 1290 patients in their study, 
259 were treated for 1-3 days and 1031 were treated for $>3$ days. There were no differences between patients who received short- or long-term treatment in terms of time to extubation, mortality, or time to discharge. The main finding of the study was that assessing serial ventilator settings can help clinicians identify patients eligible for early discontinuation of antibiotic treatment.

There are also recent studies reporting that monitoring procalcitonin may enable treatment duration to be shortened, particularly in hospital-acquired pneumonia while concluding that procalcitonin may be a powerful antibiotic management tool $[49,71,72]$

\section{Pyelonephirits/Catheter-associated Urinary} System Infection

Short-term treatment may also be used for patients with pyelonephritis or catheter-associated urinary system infections. Sandberg et al. ${ }^{[73]}$ evaluated the efficacy of ciprofloxacin for 7-14 days in females with community-acquired acute pyelonephritis (AP). One hundred twenty-six patients were given a 7-day course and 122 were given a 14-day course of ciprofloxacin. Treatment success rates were $97 \%$ and $96 \%$, respectively. The authors concluded that "Females with AP, including elderly women and patients with severe infection, can be successfully and safely treated in 7 days with oral ciprofloxacin, and therefore, shortterm antibiotics should be preferred in this age of increasing resistance".

A clinical study was carried out with 506 patients to compare the efficacy of $750 \mathrm{mg}$ levofloxacin once daily for 5 days with ciprofloxacin twice a day for 10 days in treating complicated urinary tract infections or $\mathrm{AP}^{[74]}$. Success rates at the end of treatment were $88.3 \%$ for levofloxacin and $86.7 \%$ for ciprofloxacin. There was no statistical difference between the results.

Another study ${ }^{[75]}$ included 192 patients with catheter-associated urinary tract infection and compared treatment durations of 3-5 days and 14 days. Seventy-seven of the patients were given a 3-5-day course. Both treatment durations provided similar clinical results, highlighting the fact that short-term therapy may be used in the treatment of catheter-associated urinary tract infections.

\section{Acute Otitis Media (AOM)}

AOM is a common pediatric infection that may lead to serious health problems in rare cases. One of the most controversial issues in pediatric AOM treatment is the use of antibiotics. Antibiotic therapy is recommended for children between 6 and 23 months with symptoms of earache for at least 48 hours or a fever of $39{ }^{\circ} \mathrm{C}$ or higher ${ }^{[76]}$. It is not necessary to initiate antibiotic therapy for AOM in the absence of severe symptoms. If there is no improvement or worsening of symptoms in 4872 hours, the child should be reevaluated and may require antibiotics. However, the duration of antibiotic therapy for pediatric $\mathrm{AOM}$ is a subject of debate. It has been stated that there is no difference between short-term ( $<7$ days) and longterm (7-14 days) antibiotic treatment. In a randomized study organized by Hoberman et al. ${ }^{[7]}$ and implemented in two centers in the USA, children diagnosed with AOM were randomly assigned to 10-day or 5-day courses of amoxicillin-clavulonic acid treatment. Clinical failure was defined as worsening of the signs or symptoms of infection during follow-up or the incomplete resolution of $\mathrm{AOM}$ signs and symptoms at the end of treatment. Secondary outcomes were relapse of otitis media, nasophrayngeal bacterial colonization rates, and parents' satisfaction with treatment. Clinical failure was seen in 34\% of the 10-day course group and 16\% of the 5-day course group. At least 50\% reduction in AOM symptoms was seen in $91 \%$ of the children in the 10-day treatment group and only $80 \%$ of children in 5-day treatment group. There was no significant difference between the groups in terms of residual middle ear effusion after treatment. The rate of AOM recurrence was similar between the groups, and was higher among children with residual effusion regardless of treatment received. There were also no differences between the 10-day and 5-day treatment groups in rates of nasopharyngeal colonization with penicillinresistant bacteria, adverse events, and parent satisfaction. It was stated in a meta-analysis regarding $\mathrm{AOM}^{[78]}$ that a 5 -day shortterm course of antibiotics is an effective treatment for AOM. The analysis concludes by stating that "with the estimated cost savings, improved convenience, and lower antibiotic resistance, short-term antibiotic therapy has the potential to significantly reduce antibiotic usage in regions where 10-day treatment is accepted as the standard".

\section{Complicated Intraabdominal Infections (cIAI)}

The optimal duration of antimicrobial therapy for clAl in critically ill surgical patients is unknown. Recent evidence suggests that short-term (4 days) treatment may be effective, but there are limited data for the patients with severely critical disease. In a study by Smith et al. ${ }^{[79]}, 1679 \mathrm{clAl}$ patients were divided into short-term ( $\leq 7$ days) and long-term ( $>7$ days) antimicrobial treatment groups. The short-term regimen was 5 days and the long-term regimen was 14 days. Treatment failure occurred in 39\% in patients receiving short-term therapy and 63\% in patients receiving long-term therapy $(p<0.001)$. Treatment duration was found to be correlated with treatment failure (OR: 2.886; $p=0.006)$. There was no difference in mortality between the groups (OR: 0.738; $p=0.461$ ). The authors concluded that "A 
short course of antibiotic therapy after source control in surgical patients with critical clAl yielded results similar to previous studies and supported the safety of this method in critical patients". In another study ${ }^{[80]}$, the authors stated that "Data obtained from noninferiority trials of short-term antimicrobial treatment for IAls indicate the global superiority of short-term therapy". Hence, determining whether source control has been achieved is imperative for short-term therapy.

\section{Catheter-associated Bloodstream Infection}

Catheter-associated bloodstream infections are among the leading healthcare-related infections causing severe morbidity and increased costs ${ }^{[81]}$. Most catheter-associated bloodstream infections can be prevented by taking universal preventive measures.

\section{Universal preventive measures:}

1. Enhancing collaborative performance using checklists and bundles,

2. Educating the personnel who place and maintain catheters,

3. Maximal sterile barrier precautions,

\section{Chlorhexidine skin antisepsis.}

If the incidence of catheter-associated bloodstream infection is not reduced to acceptable levels after implementing these universal measures, technological innovations such as coated catheters and antimicrobial-impregnated dressings as well as antimicrobial lock solutions should be considered. Although many experts claim that a certain period of antibiotic therapy is necessary, these infections can be resolved by catheter removal, without the need for further antibiotic treatment. It has been reported that except for endovascular infections such as septic thrombosis, endocarditis, and metastatic infections, a 5-7 day course of antibiotics course is sufficient after catheter removal ${ }^{[82]}$.

\section{Osteomyelitis}

The management of osteomyelitis requires a multidisciplinary approach combining debridement and antimicrobial treatment. Many therapeutic regimens have been designed to prevent, cure, or suppress osteomyelitis ${ }^{[83]}$. Defining treatment for these patients is difficult for several reasons. These difficulties include debridement, the effectiveness of antibiotics, heterogeneity of clinical condition and pathogens, and the need for years of follow-up to demonstrate long-term remission. Another important problem is the limited number of randomized controlled studies. Many recommendations for the treatment of osteomyelitis are based on expert opinion and not on the results of randomized-controlled studies. Therefore, standardization of treatment has not been possible. Swiontkowski et al. conducted a study comparing clinical outcomes of 93 osteomyelitis patients treated with a protocol including debridement followed by 5-7 days of intravenous antibiotics and oral treatment for 6 weeks to those of 22 patients treated with the same surgical protocol and intravenous antibiotics for 6 weeks. The authors reported that the treatment was $91 \%$ successful regardless of the active microorganism and emphasized that prolonged intravenous antibiotic therapy is not necessary for clinical recovery in adult patients with chronic osteomiyelitis ${ }^{[84]}$. In a study comparing 6 weeks and 12 weeks of treatment in patients with pyogenic vertebral osteomyelitis, both were reported to be equally effective ${ }^{[85]}$. Another study aimed at identifying the optimal duration of antibiotic use after chronic osteomyelitis surgery demonstrated no difference in recovery between a treatment of 6 weeks and longer treatments ${ }^{[86]}$. A review of articles published between 1968 and 2000 to determine the best approach to antibiotic therapy for osteomyelitis revealed that although no optimal duration was defined for antibiotherapy, most researchers treated patients for about 6 weeks. The authors stated that despite 30 years of research, the available literature on osteomyelitis treatment is insufficient to determine the best antibiotic, route of administration, and treatment duration ${ }^{[87]}$.

\section{Prosthetic Joint Infections}

Deep infection of the implant site is a destructive complication typically resulting in pain, extended hospital stays, and increased medical $\operatorname{costs}^{[88]}$. The treatment of such infections generally involves surgery and antimicrobial treatment. Although debridement and one-stage revision has been successful in selected cases, the current standard surgical procedure for managing prosthetic hip infections (PHI) is staged exchange arthroplasty (SEA) which involves total debridement of infected tissues and removal of all components, followed by a period of antibiotic treatment and eventual re-implantation of a new prosthesis ${ }^{[89]}$. An antibiotic-loaded cement spacer (ALCS) is used both as a temporary hip joint implant as well as a way to directly apply local antibiotic ${ }^{[00]}$. Studies have shown that ALCS provides in vivo high efficacy with antibiotic levels much higher than those achieved by systemic antibiotics and maintains levels far above the required therapeutic concentration for several months ${ }^{[91,92]}$. Therefore, ALCS implantation has become a common approach. Although SEA is successful, the optimal duration of systemic antibiotic treatment has not been determined. In a study in which ALCS was used in 114 patients with PHI, Stockley et al. ${ }^{[93]}$ reported successful infection control in 87.7\% (100/114) without prolonged systemic antibiotic therapy. In a multicenter study, Nelson et al. ${ }^{[94]}$ applied a prospective, randomized protocol to 28 patients with infected total knee and hip arthroplasties (22 
hip and 6 knee); one group was treated with debridement and ALCS, the other with debridement and systemic antibiotherapy. The mean follow-up period was about 3 years ( 6 months- 5.6 years). The results of both groups were similar in terms of relapse and treatment success. However, due to a lack of comparative studies of the appropriate duration of SEA using ALCS, the interim use of ALCS could not be evaluated. In that sense, a study by Hsieh et al. ${ }^{[90]}$ was the first to compare the outcomes of short- and long-term systemic antibiotic therapy in patients with infected hip arthroplasty undergoing SEA with ALCS. The study included 99 patients, 46 who received standard (4-6 weeks) antibiotic treatment and 53 who received shortterm ( 1 week) treatment, and the average follow-up period was 43 months (24-60 months) regardless of infection. The success rate in both groups was approximately $90 \%$. The authors also stated that 5 patients $(11 \%)$ in the long-term treatment group developed complications related to antibiotic use, while patients in the short-term treatment group had shorter hospital stays and lower medical expenses ${ }^{[95]}$. In another study comparing 6 weeks and 12 weeks of postoperative antibiotic therapy in the treatment of prosthetic joint infections, the 6-week antibiotic course was reported to be sufficient ${ }^{[96]}$. Although the literature contains many studies investigating length of treatment, there is still a need for randomized controlled studies to determine optimal treatment durations.

\section{Conclusion}

In conclusion, the inappropriate or excessive use of antibiotics may manifest as superinfection with different bacteria, selection for resistant bacteria, and subsequent colonization/infection with MDR bacteria, which are referred to as collateral damage. The potential collateral damage should be considered in addition to the benefits of treatment when choosing antibiotic therapy. With better antibiotic stewardship, the benefits can be enhanced while reducing antibiotic-related collateral damage. Short-term antibiotic therapy may be adminstered to selected patient groups both in community- and hospital-acquired infections based on patients' individual characteristics and their clinical response to treatment (Table 2). The negative consequences of prolonged antibiotic use, such as antibiotic-related side effects and resistance, can be prevented by practicing the rational use of antibiotics together with treatment response monitoring and establishing optimum treatment durations.

Table 2. Studies evaluating short- and long-term antibiotic use

\begin{tabular}{|c|c|c|c|c|c|}
\hline Study & Disease & \begin{tabular}{|l|} 
Short-term \\
regimen
\end{tabular} & Long-term regimen & $\begin{array}{l}\text { Patient } \\
\text { number }\end{array}$ & Conclusion \\
\hline Socan ${ }^{[56]}$ & $\begin{array}{l}\text { Community-acquired } \\
\text { pneumonia }\end{array}$ & Azithromycin, 3 days & Azithromycin, 5 days & 148 & No difference in clinical success \\
\hline $\begin{array}{l}\text { Hoepelman et } \\
\text { al. }{ }^{[58]}\end{array}$ & $\begin{array}{l}\text { Community-acquired } \\
\text { pneumonia }\end{array}$ & Azithromycin, 3 days & $\begin{array}{l}\text { Amoxicillin/clavunate, } \\
10 \text { days }\end{array}$ & 144 & No difference in clinical success \\
\hline Peltola et al ${ }^{[52]}$ & $\begin{array}{l}\text { Community-acquired } \\
\text { pneumonia }\end{array}$ & $\begin{array}{l}\text { Cefuroxime or } \\
\text { penicillin G, } 4 \text { days }\end{array}$ & $\begin{array}{l}\text { Cefuroxime or penicillin } \\
\text { G, } 7 \text { days }\end{array}$ & 154 & No difference in clinical success \\
\hline Dunbar et al $\left.\right|^{[54]}$ & $\begin{array}{l}\text { Community-acquired } \\
\text { pneumonia }\end{array}$ & Levofloxacin, 5 days & Levofloxacin, 10 days & 528 & No difference in clinical success \\
\hline Yilmaz et al. ${ }^{[49]}$ & $\begin{array}{l}\text { Ventilator-associated } \\
\text { pneumonia }\end{array}$ & $\begin{array}{l}\text { 7-10 days of therapy } \\
\text { based on 5-day } \\
\text { clinical evaluation }\end{array}$ & $\begin{array}{l}>10 \text { days of therapy } \\
\text { based on } 5 \text {-day clinical } \\
\text { evaluation }\end{array}$ & 49 & $\begin{array}{l}\text { No difference in clinical success } \\
\text { Number of days without } \\
\text { antibiotics was higher in patients } \\
\text { who received short-term } \\
\text { treatment }\end{array}$ \\
\hline Sandberg et al. ${ }^{[73]}$ & Pyelonephritis & Ciprofloxacin, 7 days & Ciprofloxacin, 14 days & 248 & No difference in clinical success \\
\hline Jarrell et al. ${ }^{[75]}$ & $\begin{array}{l}\text { Catheter-associated } \\
\text { urinary tract infection }\end{array}$ & $\begin{array}{l}\text { 3-5 days of therapy } \\
\text { based on clinical } \\
\text { evaluation }\end{array}$ & $\begin{array}{l}14 \text { days of therapy } \\
\text { based on clinical } \\
\text { evaluation }\end{array}$ & 192 & No difference in clinical success \\
\hline Hoberman et al. ${ }^{[77]}$ & Acute otitis media & $\begin{array}{l}\text { Amoxicillin/ } \\
\text { clavulonic acid, } 5 \\
\text { days }\end{array}$ & $\begin{array}{l}\text { Amoxicillin/clavulonic } \\
\text { acid, } 10 \text { days }\end{array}$ & 520 & No difference in clinical success \\
\hline $\begin{array}{l}\text { Swiontkowski et } \\
\text { al. }^{[84]}\end{array}$ & Osteomyelitis & $\begin{array}{l}\text { Debridement }+5-7 \\
\text { days IV }+6 \text { weeks } \\
\text { oral antibiotic }\end{array}$ & $\begin{array}{l}\text { Debridement + } 6 \text { weeks } \\
\text { IV antibiotic }\end{array}$ & 115 & No difference in clinical success \\
\hline Bernard et al. ${ }^{[85]}$ & Osteomyelitis & 6 weeks antibiotic & 12 weeks antibiotic & 359 & No difference in clinical success \\
\hline Nelson et al..$^{[94]}$ & $\begin{array}{l}\text { Infected knee and total } \\
\text { hip arthroplasty }\end{array}$ & $\begin{array}{l}\text { Debridement + } \\
\text { antibacterial ALCS }\end{array}$ & $\begin{array}{l}\text { Debridement + systemic } \\
\text { antibiotherapy }\end{array}$ & 28 & No difference in clinical success \\
\hline Bernard et al. ${ }^{[95]}$ & Prosthetic joint infections & 6 weeks antibiotic & 12 weeks antibiotic & 144 & 6-week treatment is adequate \\
\hline
\end{tabular}

ALCS: Antibiotic-loaded cement spacer, IV: Intravenous 


\section{Ethics}

Peer-review: Externally and internally peer-reviewed.

\section{Authorship Contributions}

Concept: G.Y., S.A., U.K., Design: G.Y., S.A., U.K., Data Collection or Processing: G.Y., S.A., U.K., Analysis or Interpretation: G.Y., S.A., U.K., Literature Search: G.Y., S.A., U.K., Writing: G.Y., S.A., U.K.

Conflict of Interest: No conflict of interest was declared by the authors.

Financial Disclosure: The authors declared that this study received no financial support.

\section{References}

1. Dellinger RP, Levy MM, Rhodes A, Annane D, Gerlach H, Opal SM, Sevransky JE, Sprung CL, Douglas IS, Jaeschke R, Osborn TM, Nunnally ME, Townsend SR, Reinhart K, Kleinpell RM, Angus DC, Deutschman CS, Machado FR, Rubenfeld GD, Webb S, Beale RJ, Vincent JL, Moreno R; Surviving Sepsis Campaign Guidelines Committee including The Pediatric Subgroup. Surviving Sepsis Campaign: international guidelines for management of severe sepsis and septic shock, 2012. Intensive Care Med. 2013;39:165-228.

2. Barlam TF, Cosgrove SE, Abbo LM, MacDougall C, Schuetz AN, Septimus EJ, Srinivasan A, Dellit TH, Falck-Ytter YT, Fishman NO, Hamilton CW, Jenkins TC, Lipsett PA, Malani PN, May LS, Moran GJ, Neuhauser MM, Newland JG, Ohl CA, Samore MH, Seo SK, Trivedi KK. Implementing an Antibiotic Stewardship Program: Guidelines by the Infectious Diseases Society of America and the Society for Healthcare Epidemiology of America. Clin Infect Dis. 2016;62:51-77.

3. World Health Organization (WHO). The Rational Use of Drugs: Report of Conference of Experts on Nairobi, Kenya, 25-29 November 1985. Last accessed date: 2 July 2017. Available from: http://www.who.int

4. Rogawski ET, Platts-Mills JA, Seidman JC, John S, Mahfuz M, Ulak M, Shrestha SK, Soofi SB, Yori PP, Mduma E, Svensen E, Ahmed T, Lima AA, Bhutta ZA, Kosek MN, Lang DR, Gottlieb M, Zaidi AK, Kang G, Bessong PO, Houpt ER, Guerrant RL. Use of antibiotics in children younger than two years in eight countries: a prospective cohort study. Bull World Health Organ. 2017;95:49-61.

5. Ulusal Antibakteriyel İlaç Tüketim Sürveyansı - 2011. Sağlık Bakanlığı Yayın No: 995. TiтCK Yayın No: 001. Ankara-2015. ISBN: 978-975-590-540-2. Last accessed date: 2 July 2017 Available from: http://www.akilciilac.gov.tr/wpcontent/uploads/2015/06/svy.pdf

6. Versporten A, Bolokhovets G, Ghazaryan L, Abilova V, Pyshnik G, Spasojevic T, Korinteli I, Raka L, Kambaralieva B, Cizmovic L, Carp A, Radonjic V, Maqsudova N, Celik HD, Payerl-Pal M, Pedersen HB, Sautenkova N, Goossens $\mathrm{H} ;$ WHO/Europe-ESAC Project Group. Antibiotic use in eastern Europe: a cross-national database study in coordination with the WHO Regional Office for Europe. Lancet Infect Dis. 2014;14:381-7.

7. Le Grand A, Hogerzeil HV, Haaijer-Ruskamp FM. Intervention research in rational use of drugs: a review. Health Policy Plan. 1999;14:89-102.

8. American Thoracic Society; Infectious Diseases Society of America. Guidelines for the management of adults with hospital acquired ventilatorassociated and healthcare-associated pneumonia. Am J Respir Crit Care Med. 2005;171:388-416.

9. Martin-Loeches I, Torres A. A week seems to be weak: tailoring duration of antibiotic treatment in Gram-negative ventilator-associated pneumonia. Crit Care. 2013:17:106.

10. Martinez JL. General principles of antibiotic resistance in bacteria. Drug Discov Today Technol. 2014;11:33-9.
11. Niederman MS. Principles of appropriate antibiotic use. Int J Antimicrob Agents. 2005;26(Suppl 3):170-5.

12. Kollef MH. Optimizing antibiotic therapy in the intensive care unit setting. Crit Care. 2001;5:189-95.

13. Centers for Disease Control and Prevention (CDC). Core elements of hospital antibiotic stewardship programs. Last accessed date: 2 July 2017. Available from: https://www.cdc.gov/antibiotic-use/healthcare/implementation/ core-elements.html

14. Gonzales R, Malone DC, Maselli JH, Sande MA. Excessive antibiotic use for acute respiratory infections in the United States. Clin Infect Dis. 2001;33:757-62.

15. Devrim I, Gülfidan G, Oruç Y, Yaşar N, Sorguç Y, Ayhan FY, Bayram N, Ünal N. Point-Prevalence Study Relating to Antibiotic Usage in Dr. Behçet Uz Children Hospital; Comparison of 2008 and 2012 Data. J Pediatr Inf. 2012;6:46-9.

16. Pigrau-Serrallach C, Rodriguez-Pardo D. Bone and joint tuberculosis. Eur Spine J. 2013;22(Suppl 4):556-66.

17. Colmenero JD, Jime'nez-Mejias ME, Reguera JM, Palomino-Nicas J, RuizMesa JD, Marquez-Rivas J, Lozano A, Pachon J. Tuberculous vertebral osteomyelitis in the new millennium: still a diagnostic and therapeutic challenge. Eur J Clin Microbiol Infect Dis. 2004;23:477-83.

18. Neu HC, Howrey SP. Testing the physician's knowledge of antibiotic use: selfassessment and learning via videotape. N Engl J Med. 1975;293:1291-5.

19. Holubar M, Deresinsky S. Antimicrobial stewardship in hospital settings. Last accessed date: 30.05.2018 Available from: https://www.uptodate.com/ contents/antimicrobial-stewardship-in-hospital-settings

20. Avkan-Oğuz V, Baykam N, Sökmen S, Güner R, Agalar F, Alp E, Doğrul A, Turhan Ö, Ağalar C, Kurtaran B, Geçim IE, Özaras R, Yılmaz G, Akbulut A, Koksal i. Recommendations for intra-abdominal infections consensus report. Ulus Cerrahi Derg. 2016;32:306-21.

21. Ariza J, Bosilkovski M, Cascio A, Colmenero JD, Corbel MJ, Falagas ME, Memish ZA, Roushan MR, Rubinstein E, Sipsas NV, Solera J, Young EJ, Pappas G; International Society of Chemotherapy; Institute of Continuing Medical Education of Ioannina. Perspectives for the Treatment of Brucellosis in the 21 $1^{\text {st }}$ Century: The loannina Recommendations. PLoS Med. 2007;4:e317.

22. Nahid $\mathrm{P}$, Dorman SE, Alipanah N, Barry PM, Brozek JL, Cattamanchi A, Chaisson LH, Chaisson RE, Daley CL, Grzemska M, Higashi JM, Ho CS, Hopewell PC, Keshavjee SA, Lienhardt C, Menzies R, Merrifield C, Narita M, O'Brien R, Peloquin CA, Raftery A, Saukkonen J, Schaaf HS, Sotgiu G, Starke JR, Migliori GB, Vernon A. Official American Thoracic Society/Centers for Disease Control and Prevention/Infectious Diseases Society of America Clinical Practice Guidelines: Treatment of Drug-Susceptible Tuberculosis. Clin Infect Dis. 2016;63:e147.

23. Lepper MH, Dowling HF. Treatment of pneumococcic meningitis with penicillin compared with penicillin plus aureomycin; studies including observations on an apparent antagonism between penicillin and aureomycin. AMA Arch Intern Med. 1951;88:489-94.

24. Mathies AW Jr, Leedom JM, Ivler D, Wehrle PF, Portnoy B. Antibiotic antagonism in bacterial meningitis. Antimicrob Agents Chemother (Bethesda). 1967;7:218-24.

25. Eliopoulos GM, Moellering RC. Principles of Anti-infective Therapy. In: Mandell GL, Bennett JE, Dolin R (eds). Mandell, Douglas and Bennett's Principles and Practice of Infectious Diseases. $8^{\text {th }}$ ed. Philadelphia: 2015;17:224-33.

26. Sande MA, Overton JW. In vivo antagonism between gentamicin and chloramphenicol in neutropenic mice. J Infect Dis. 1973;128:247-50.

27. McLaughlin JE, Reeves DS. Clinical and laboratory evidence for inactivation of gentamicin by carbenicillin. Lancet. 1971;1:261-4. 
28. White DG, Shao S, Sudler R, Ayers $S$, Friedman $S$, Chen S, McDermott PF, McDermott $S$, Wagner DD, Meng J. The isolation of antibiotic-resistant Salmonella from retail ground meats. N Engl J Med. 2001;345:1147-54.

29. Sorensen TL, Blom M, Monnet DL, Frimoldt-Moller N, Poulsen RL, Espersen F. Transient carriage after ingestion of antibiotic-resistant Enterococcus faecium from chicken and pork. N Engl J Med. 2001;345:1161-6.

30. McDonald LC, Rossiter S, Mackinson C, Wang YY, Johnson S, Sullivan M, Sokolow R, DeBess E, Gilbert L, Benson JA, Hill B, Angulo FJ. Quinupristindalfopristin-resistant Enterococcus faecium on chicken and in human stool specimens. N Engl J Med. 2001;345:1155-60.

31. Akıcı $A$, Uğurlu MÜ, Gönüllü N, Oktay Ş, Kalaça S. Pratisyen Hekimlerin Akılcı İlaç Kullanımı Konusunda Bilgi ve Tutumlarının Değerlendirilmesi. Sted. 2002;11:253-6.

32. World Health Organization (WHO). WHO Policy perspectives on medicines. Promoting rational use of medicines: core components. Geneva, Sep 2002. Last available date: 1 July 2017. Available from: www.who.com

33. Le Grand A, Hogerzeil HV, Haaijer-Ruskamp FM. Intervention research in rational use of drugs: a review. Health Policy Plan. 1999;14:89-102.

34. Baron S. Medical Microbiology. 4th edition. Chapter 6 Normal Flora. University of Texas Medical Branch at Galveston; 1996. Last accessed date: 2 July 2017 Available from: https://www.ncbi.nlm.nih.gov/books/NBK7617

35. Cho I, Blaser MJ. The human microbiome: at the interface of health and disease. Nat Rev Genet. 2012;13:260-70.

36. Falagas ME, Rafailidis PI, Makris GC. Bacterial interference for the prevention and treatment of infections. Int J Antimicrob Agents. 2008;31:518-22.

37. Brook I. Bacterial interference. Crit Rev Microbiol. 1999;25:155-72.

38. Wooley RE, Brown J, Gibbs PS, Nolan LK, Turner KR. Effect of Normal Intestinal Flora of Chickens on Colonization by Virulent Colicin V-Producing, Avirulent, and Mutant Colicin V-Producing Avian Escherichia coli. Avian Dis. 1994;38:141-5.

39. Jandhyala SM, Talukdar $R$, Subramanyam $C$, Vuyyuru $H$, Sasikala $M$, Nageshwar Reddy D. Role of the normal gut microbiota. World J Gastroenterol. 2015;21:8787-803.

40. Doron S, Davidson LE. Antimicrobial Stewardship Mayo Clin Proc. 2011;86:1113-23.

41. Leung E, Weil DE, Raviglione M, Nakatani H; World Health Organization World Health Day Antimicrobial Resistance Technical Working Group. The WHO policy package to combat antimicrobial resistance. Bull World Health Organ. 2011;89:390-2.

42. Jernberg C, Löfmark S, Edlund C, Jansson JK. Long-term impacts of antibiotic exposure on the human intestinal microbiota. Microbiology. 2010;156:3216-23.

43. Rafii $F$, Sutherland JB, Cerniglia CE. Effects of treatment with antimicrobial agents on the human colonic microflora. Ther Clin Risk Manag. 2008;4:1343-58.

44. Al-Nassir WN, Sethi AK, Li Y, Pultz MJ, Riggs MM, Donskey CJ. Both oral metronidazole and oral vancomycin promote persistent overgrowth of vancomycin-resistant enterococci during treatment of Clostridium difficileassociated disease. Antimicrob Agents Chemother. 2008;52:2403-6.

45. De La Cochetière MF, Durand T, Lepage $P$, Bourreille $A$, Galmiche JP, Doré $J$. Resilience of the dominant human fecal microbiota upon short-course antibiotic challenge. J Clin Microbiol. 2005;43:5588-92.

46. Edlund $C$, Nord CE. Effect on the human normal microflora of oral antibiotics for treatment of urinary tract infections. J Antimicrob Chemother. 2000;46(Suppl 1):41-8.

47. Friedrich MJ. Unraveling the influence of gut microbes on the mind. JAMA;2015;313:1699-701.

48. Kalil AC, Metersky ML, Klompas M, Muscedere J, Sweeney DA, Palmer LB, Napolitano LM, O'Grady NP, Bartlett JG, Carratalà J, El Solh AA, Ewig S, Fey PD, File TM Jr, Restrepo MI, Roberts JA, Waterer GW, Cruse P, Knight SL, Brozek JL. Management of Adults With Hospital-acquired and Ventilator- associated Pneumonia: Clinical Practice Guidelines by the Infectious Diseases Society of America and the American Thoracic Society. Clin Infect Dis. 2016;63:61-111.

49. Yilmaz G, Saylan S, Aksoy F, Köksal I. Individualized Antibiotic Therapy in Patients with Ventilator-Associated Pneumonia. J Med Microbiol. 2017;66:78-82.

50. Mandell LA, Wunderink RG, Anzueto A, Bartlett JG, Campbell GD, Dean NC, Dowell SF, File TM Jr, Musher DM, Niederman MS, Torres A, Whitney CG; Infectious Diseases Society of America; American Thoracic Society. Infectious Diseases Society of America/American Thoracic Society consensus guidelines on the management of community-acquired pneumonia in adults. Clin Infect Dis. 2007;44(Suppl 2):27-72.

51. Sener B. Collateral Damage and Antibiotic Resistance. ANKEM Derg. $2011 ; 26: 288-92$.

52. Peltola H, Vuori-Holopainen E, Kallio MJ; SE-TU Study Group. Succesful shortening from seven to four days of parenteral beta-lactam treatment for common chilhood infections: A prospective and randomized study. Int J Infect Dis. 2001;5:3-8.

53. Schrag SJ, Peña $C$, Fernández J, Sánchez J, Gómez V, Pérez E, Feris JM, Besser RE. Effect of short-course, high dose amoxicillin therapy on resistant pneumococcal carriage: A randomised trial. JAMA. 2001;286:49-56.

54. Dunbar LM, Khashab MM, Kahn JB, Zadeikis N, Xiang JX, Tennenberg AM. Efficacy of $750 \mathrm{mg}, 5$ day levofloxacin in the treatment of communityacquired pneumonia caused by atypical pathogens. Curr Med Res Opin. 2004;20:555-63.

55. Kiter G. Azithromycin in the treatment of adults with mild to moderate community-acquired pneumonia: A study of efficacy and tolerability. Meandros Med Dent J. 2000;1:11-5.

56. Socan M. Treatment of atypical pneumonia with azithromycin: comparison of a 5-day and a 3-day course. J Chemother. 1998;10:64-8.

57. Schönwald S, Kuzman I, Oreskovic K, Burek V, Skerk V, Car V, Bozinović $\mathrm{D}$, Culig J, Radosević S. Azithromycin: single $1.5 \mathrm{~g}$ dose in the treatment of patients with atypical pneumonia syndrome--a randomized study. Infection. 1999;27:198-202.

58. Hoepelman IM, Möllers MJ, van Schie MH, Greefhorst AP, Schlösser NJ, Sinninghe Damsté EJ, van de Moosdijk CN, Dalinghaus WH, Eland ME, Mol SJ, Rozenberg-Arska M. A short (3 day) course of azithromycin tablets versus a 10-day course of amoxycillin-clavulanic acid in the treatment of adults with lower respiratory tract infections and effects on long term outcome. Int J Antimicrob Agents. 1997;9:141-6.

59. Tellier G, Niederman MS, Nusrat $R$, Patel M, Lavin B. Clinical and bacteriological efficacy and safety of 5 and 7 day regimens of telithromycin once daily compared with a 10 day regimen of chlarithromycin twice daily in patients with mild to moderate community-acquired pneumonia. J Antimicrob Chemother. 2004;54:515-23.

60. Li JZ, Winston LG, Moore DH, Bent S. Efficacy of short course antibiotic regimens for community-acquired pneumonia: A meta-analysis. Am J Med. 2007; 120:783-90.

61. El Moussaoui $R$, de Borgie CA, van den Broek P, Hustinx WN, Bresser $P$, van den Berk GE, Poley JW, van den Berg B, Krouwels FH, Bonten MJ, Weenink C, Bossuyt PM, Speelman P, Opmeer BC, Prins JM. Effectiveness of discontinuing antibiotic treatment after three days versus eight days in mild to moderate-severe community acquired pneumonia: randomised, double blind study. BMJ. 2006;332:1355.

62. Lim WS, Baudouin SV, George RC, Hill AT, Jamieson C, Le Jeune I, Macfarlane JT, Read RC, Roberts HJ, Levy ML, Wani M, Woodhead MA; Pneumonia Guidelines Committee of the BTS Standards of Care Committee. BTS guidelines for the management of community acquired pneumonia in adults: update 2009. Thorax. 2009;64(Suppl 3):1-55.

63. Bradley JS, Byington CL, Shah SS, Alverson B, Carter ER, Harrison C, Kaplan SL, Mace SE, McCracken GH Jr, Moore MR, St Peter SD, Stockwell JA, Swanson 
JT; Pediatric Infectious Diseases Society and the Infectious Diseases Society of America. The management of community-acquired pneumonia in infants and children older than 3 months of age: clinical practice guidelines by the Pediatric Infectious Diseases Society and the Infectious Diseases Society of America. Clin Infect Dis. 2011;53:25-76.

64. Capelastegui A, Espana Yandiola PP, Quintana JM, Bilbao A, Diez R, Pascual $\mathrm{S}$, Pulido E, Egurrola M. Predictors of short-term rehospitalization following discharge of patients hospitalized with community-acquired pneumonia. Chest. 2009;136:1079-85.

65. Jasti H, Mortensen EM, Obrosky DS, Kapoor WN, Fine MJ. Causes and risk factors for rehospitalization of patients hospitalized with communityacquired pneumonia. Clin Infect Dis. 2008;46:550-6.

66. Klompas M. Nosocomial pneumoniae. In: Mandell GL, Bennett JE, Dolin R (eds). Mandell, Douglas and Bennett's Principles and Practice of Infectious Diseases. $8^{\text {th }}$ edition. Philadelphia: 2015;303:3325-33.

67. Fishman JA. Nosocomial pneumoniae. In: Grippi MA, Elias JA, Fishman JA, Kotloff RM, Pack Al, Senior RM, Siegel MD (eds). Fishman's pulmonary diseases and disorders $4^{\text {th }}$ ed. New York: Mc Graw-Hill Companies, 2008:2273-90.

68. Martin-Loeches I, Torres A. A week seems to be weak: tailoring duration of antibiotic treatment in Gram-negative ventilator-associated pneumonia. Crit Care. 2013;17:106.

69. Silva CD, Silva Júnior M. Strategies for appropriate antibiotic use in intensive care unit. Einstein (Sao Paulo). 2015;13:448-53.

70. Klompas M, Li L, Menchaca JT, Gruber S; Centers for Disease Control and Prevention Epicenters Program. Ultra-Short-Course Antibiotics for Patients With Suspected Ventilator-Associated Pneumonia but Minimal and Stable Ventilator Settings. Clin Infect Dis. 2017;64:870-6.

71. Rhee C. Using Procalcitonin to Guide Antibiotic Therapy. Open Forum Infect Dis. 2016;4:ofw249.

72. Stolz D, Smyrnios N, Eggimann $P$, Pargger $H$, Thakkar N, Siegemund $M$, Marsch S, Azzola A, Rakic J, Mueller B, Tamm M. Procalcitonin for reduced antibiotic exposure in ventilator-associated pneumonia: a randomised study. Eur Respir J. 2009;34:1364-75.

73. Sandberg $T$, Skoog $G$, Hermansson $A B$, Kahlmeter $G$, Kuylenstierna $N$, Lannergård $A$, Otto G, Settergren B, Ekman GS. Ciprofloxacin for 7 days versus 14 days in women with acute pyelonephritis: a randomised, openlabel and double-blind, placebo-controlled, non-inferiority trial. Lancet. 2012;380:484-90.

74. Peterson J, Kaul S, Khashab M, Fisher AC, Kahn JB. A double-blind, randomized comparison of levofloxacin $750 \mathrm{mg}$ once-daily for five days with ciprofloxacin 400/500 mg twice-daily for 10 days for the treatment of complicated urinary tract infections and acute pyelonephritis. Urology. 2008;71:17-22.

75. Jarrell AS, Wood GC, Ponnapula S, Magnotti U, Croce MA, Swanson JM, Boucher BA, Fabian TC. Short-duration treatment for catheter-associated urinary tract infections in critically ill trauma patients. J Trauma Acute Care Surg. 2015;79:649-53.

76. Lieberthal AS, Carroll AE, Chonmaitree T, Ganiats TG, Hoberman A, Jackson MA, Joffe MD, Miller DT, Rosenfeld MD, Sevilla XD, Schwartz RH, Thomas PA, Tunkel DE. The diagnosis and management of acute otitis media. Pediatrics. 2013;131:964-99.

77. Hoberman A, Paradise JL, Rockette HE, Kearney DH, Bhatnagar S, Shape TR, Martin JM, Kurs-Lasky M, Copelli SJ, Colborn K, Block SL, Labella JJ, Lynch TG, Cohen NL, Haralam M, Pope MA, Nagg JP, Green MD, Shaikh N.
Shortened antimicrobial treatment for acute otitis media in young children. N Engl J Med. 2016;375:2446-56.

78. Kozyrskyj AL, Hildes-Ripstein GE, Longstaffe SE, Wincott JL, Sitar DS, Klassen TP, Moffatt ME. Treatment of acute otitis media with a shortened course of antibiotics: a meta-analysis. JAMA. 1998;279:1736-42.

79. Smith SE, Rumbaugh KA, May AK. Evaluation of a Short Course of Antimicrobial Therapy for Complicated Intra-Abdominal Infections in Critically III Surgical Patients. Surg Infect (Larchmt). 2017;18:742-50.

80. Celestin AR, Odom SR, Angelidou K, Evans SR, Coimbra R, Guidry CA, Cuschieri J, Banton KL, O'Neill PJ, Askari R, Namias N, Duane TM, Claridge JA, Dellinger EP, Sawyer RA, Cook CH. Novel Method Suggests Global Superiority of Short-Duration Antibiotics for Intra-abdominal Infections. Clin Infect Dis. 2017;16;65:1577-9.

81. Hewlett AL, Rupp ME. New Developments in the Prevention of Intravascular Catheter Associated Infections. Infect Dis Clin North Am. 2012;26:1-11.

82. Pagani JL, Eggimann P. Management of catheter-related infection. Expert Rev Anti Infect Ther. 2008;6:31-7.

83. Carek PJ, Dickerson LM, Sack JL. Diagnosis and management of osteomyelitis. Am Fam Physician. 2001;63:2413-20.

84. Swiontkowski MF, Hanel DP, Vedder NB, Schwappach JR. A comparison of short- and long-term intravenous antibiotic therapy in the postoperative management of adult osteomyelitis. J Bone Joint Surg Br. 1999;81:1046-50.

85. Bernard L, Dinh A, Ghout I, Simo D, Zeller V, Issartel B, Le Moing V, Belmatoug $N$, Lesprit P, Bru JP, Therby A, Bouhour D, Dénes E, Debard A, Chirouze C, Fèvre $K$, Dupon $M$, Aegerter $P$, Mulleman $D$; Duration of Treatment for Spondylodiscitis (DTS) study group. Antibiotic treatment for 6 weeks versus 12 weeks in patients with pyogenic vertebral osteomyelitis: an open-label, non-inferiority, randomised, controlled trial. Lancet. 2015;385:875-82.

86. Rod-Fleury T, Dunkel N, Assal M, Rohner P, Tahintzi P, Bernard L, Hoffmeyer $P$, Lew D, Uçkay I. Duration of post-surgical antibiotic therapy for adult chronic osteomyelitis: a single-centre experience. Int Orthop. 2011;35:172531.

87. Lazzarini L, Lipsky BA, Mader JT. Antibiotic treatment of osteomyelitis: what have we learned from 30 years of clinical trials? Int J Infect Dis. 2005;9:12738.

88. Hanssen AD, Rand JA. Evaluation and treatment of infection at the site of a total hip or knee arthroplasty. Instr Course Lect. 1999;48:111-22.

89. Salvati EA, Gonzalez Della Valle A, Masri BA, Duncan CP. The infected total hip arthroplasty. Instr Course Lect. 2003;52:223-45.

90. Hsieh PH, Shih CH, Chang YH, Lee MS, Shih HN, Yang WE. Two-stage revision hip arthroplasty for infection: comparison between the interim use of antibiotic-loaded cement beads and a spacer prosthesis. J Bone Joint Surg. 2004;86:1989-97.

91. Masri BA, Duncan CP, Beauchamp CP. Long-term elution of antibiotics from bone-cement: an in vivo study using the prosthesis of antibiotic-loaded acrylic cement (PROSTALAC) system. J Arthroplasty. 1998;13:331-8.

92. Hsieh $\mathrm{PH}$, Chang $\mathrm{YH}$, Chen $\mathrm{SH}$, Ueng $\mathrm{SW}$, Shih $\mathrm{CH}$. High concentration and bioactivity of vancomycin and aztreonam eluted from Simplex cement spacers in two-stage revision of infected hip implants: a study of 46 patients at an average follow-up of 107 days. J Orthop Res. 2006;24:161521.

93. Stockley I, Mockford BJ, Hoad-Reddick A, Norman P. The use of twostage exchange arthroplasty with depot antibiotics in the absence oflong-term antibiotic therapy in infected total hip replacement. J Bone Joint Surg Br. 2008;90:145-8. 